\title{
Performance Official Food Control in The Republic of Moldova: Results And Interpretations For 2016-2019
}

\author{
Vitalii ZANET and Silvius STANCIU
}

“Dunărea de Jos” University of Galați, România

Correspondence should be addressed to: Vitalii ZANET; zanet_vitalii@mail.ru.

Received date: 28 April 2020; Accepted date:3 June 2021; Published date: 15 September 2021

Academic Editor: TINDECHE CRISTIANA

Copyright (C) 2021. Vitalii ZANET and Silvius STANCIU. Distributed under Creative Commons Attribution 4.0 International CC-BY 4.0

\begin{abstract}
This study represents a trend of nonconformities analysis, established by authority for safety of aliments in matter of food safety. At the same time, this study presents the rate of noncompliance at the level of enterprises in relation to the number of controls performed during 2016-2019. During the analyzed period, there has been ascertained an essential increase in the number of official controls. Following the statistical analysis, there has been proved that the highest non-compliance rate is in the field of trade and public catering units (36.6\%), in rapport with other control systems. This area represents the most balanced proportion of non-conformities detected in relation to the number of controls performed as well. Statistical analysis highlighted that on certain official control systems performed by the control authority, the high frequency of official controls is motivated by the results of previous controls.
\end{abstract}

Keywords: Quality, Official Control, Official Control System, Non - Compliance.

\section{Introduction}

At global level, good safety in recent decades has become an increasing concern. Regardless of the differences between states or regions, be it socio-economic, political, each individual owns a fundamental right - the right to consume healthy food. However, this desideratum is achieved at the state level depending on the capabilities of the control authorities in the field of food safety and the responsibility of the economic operators in the food industries. 
In the Republic of Moldova in 2018 there was registered an important step in modernizing the legislative framework in the field of food safety, aimed at achieving a high level of protection of human health and consumer interests in relation to food safety. Law no. 306/2018 on food safety transposes the general criteria provided at EU level according to the general legislative provisions of EC No 178/2002. The mentioned normative act establishes the general competences of the food safety control and supervision authorities, as well as the responsibility of the operator in the food field. The authority with control attributions for food safety in the Republic of Moldova is the National Agency for Food Safety (ANSA). The creation of ANSA in 2013 aimed at unifying the official control system into an integrated system throughout the food chain. The official controls in the field of food safety are performed by the control authority based on the Multiannual Control Plan 2019-2022 (PMC). The multi-annual control plan was developed for the first time with the support of the BMZ / GIZ project "Amelioration Food Safety in the Republic of Moldova", and aims to planification and performance of official controls in accordance with EU requirements provided in the normative acts (EC No 852/2004, 2004; EC No 853/2004, 2004; EC No 2073/ 2005). At performing controls for food safety, the control authority is obliged to correlate the control actions in accordance with Law no. $131 / 2012$ on performing state controls on entrepreneurial activity. Although in the Republic of Moldova the application of the Hazard Analysis and Critical Control Point System (HACCP) quality system has become mandatory since 1998, this opportunity to reduce food risk has not been fully implemented by operators.

Reforming of the National Standardization System presents an essential prerogative for economic operators in the food sector. Despite the fact that in the Republic of Moldova there have been adopted by ISO 700 international standards, of which 482 EU, however, they refer only to testing methods. The applied standards related to the product specifications are the old GOST from the Soviet period (Government of the Republic of Moldova, 2018).

Although food business operators have a responsibility to provide safe food, they should also have the main legal responsibility for food safety. In the absence of massive application of quality systems such as HACCP, the risk analysis and responsibility for the safe food is largely assumed by the competent authority for official control in the field of food safety.

\section{Literature Review}

The existence of a cohesive and without gaps regulation in the regulatory official control system, applied at all stages of production can minimize food risks. Statistical analysis, both qualitative and quantitative, can substantially help control planning and improve quality, so the use of statistical strategies will improve productivity, prevent unnecessary process adjustments, provide diagnostic information and provide directions for a cost-effective quality system (Steven M. Buco, 1990). Assessing the proportion of economic operators subject to control and food inspected according to the degree of risk is a major challenge. The calculation of the non-compliance rate in relation to the control rate presents a method of evaluation of different product groups or categories of economic operators (J. Lueckla, K. Weyermaira, M. Mattb, K. Mannerc and K. Fuchsa, 2019).

\section{Materials and Methods}

Despite the fact that in the Republic of Moldova the normative acts provide for the assumption of internal control by economic operators in the food field such as the HACCP model, at present this initiative is poorly applied. As mentioned by the European Commission in the Regulation (EC No 178/2002, 2002), the general law on food safety, the legal responsibility for food safety lies with the food business operator. However, during the period 2002, the European Commission ascertain that although this principle exists in some Member States and in some components of food law, in other components it is either

Vitalii ZANET and Silvius STANCIU, Journal of Eastern Europe Research in Business and Economics, DOI: 10.5171/2021.138785 
not explicit or the responsibility is assumed by the competent authorities of the Member State through the control activities performs them. The Republic of Moldova is currently the model in which the competent control authority takes over most of the legal responsibility for food safety. The analysis of the results of the official controls performed based on the Multiannual Control Plan 2016-2020 (PMC), by ANSA at the period 2016-2019, represents an increased interest for the degree of noncompliance of the economic operators, in the food industry.

The statistical analysis of the results of official controls presents an increased interest for establishing and motivating the frequency of planning controls depending on the risk of the economic operator.

The authors J. Lueckla, K. Weyermaira, M. Mattb, K. Mannerc and K. Fuchsa, (2019) define the index of complaint for calculating the non-conformity rate in relation to the control rate in the form of the equation:

$$
\begin{gathered}
\text { Com In }=\text { rate of non }- \text { compliances [\%]- } \\
\text { control rate [\%] }
\end{gathered}
$$

The application of the methodology proposed by the authors can establish in the interpretation of statistical data the case of the Republic of Moldova the performance of official control in food safety. The results of the interpretation may establish the effectiveness and necessity of planning the frequency of controls on certain official control systems.

An indicator, set with positive values for the non-compliance index control system (Inc) indicates that the non-compliance rate is higher than the proportion of planned controls. It can therefore be interpreted that the authority can justify the frequency of its checks on these undertakings by placing them at a higher risk.

\section{The system of official control in the food sector in the Republic of Moldova.}

In the last decade, the Republic of Moldova has registered positive trends at the initiative of revising the package of normative acts in the field of food safety and harmonizing the practices of official control to EU requirements. The purpose of adjusting domestic producers to the requirements of international standards, in terms of food safety, animal health, plant health being the only possibility of access to the EU market.

To meet these requirements in 2013, the National Agency for Food Safety was created. Characteristic of the countries of South-Eastern Europe, especially the postSoviet ones with a control system whose control attributions and legal responsibilities are taken over by the state institutions, the Moldovan authorities delegated the responsibility ,for a transitional period to the national control authority ANSA.

The attributions of ANSA were drawn through the prism of the legislative act no. 113 of May 18, 2012 regarding the establishment of the principles and general requirements of the legislation on food safety, normative act completely revised by Law 306/2018 on food safety, in force on 01.04.2019.

The objectives pursued following the implementation of Law no. 306/2018 on food safety are:

- the application of an integrated control system throughout the food chain,

- increasing the requirements for food safety control,

- application to food safety information systems,

- aligning laboratory activities with EU requirements.

Government authorities over the last decade have been pursuing the application of European Commission standards and recommendations at Member State level. In accordance with Article 2 of Regulation (EC) No 882/2004, Member States shall establish component ministries or ministries responsible in safety food field. In the Republic of Moldova, responsibilities in the field of food safety have been delegated to the Ministry of Agriculture, Regional Development and Environment, and the 
Ministry of Occupational Health and Social Protection.

The authors P. Svrčinová and V. Janout (2018) address as a criterion for evaluating the official control system in EU Member States, actions to improve and amend normative acts to EC standards and recommendations.

Government measures carried out by the authorities of the Republic of Moldova according to the Association Agreement of the Republic of Moldova - EU (DCFTA) during 2017-2019 in the field of food safety were carried out in proportion of $31.42 \%$. In terms of technical barriers to trade, standardization, metrology, accreditation and conformity assessment out of a total of 14 actions, was achieved 0 - actions. In the field of sanitary and phytosanitary measures out of a total of 7 actions, was realised 3. (MFAEI, 2019).

The best EU Member State at meet EC recommendations is Slovakia without unfulfilled recommendations (2 component ministries) and Croatia (2 component ministries). On the other side of the reported range is Greece with (4 component ministries) with $21.35 \%$, and United Kingdom with $19.4 \%$ of the recommendations made by the EC. At Member State level, it can be deduced that the number of component ministries does not affect the efficiency of the official control system (P. Svrčinová, V. Janout 2018).

Assurance of EC recommendations by the Republic of Moldova regarding the reforming of the official control system depends on a number of socio-economic factors and political will at the level of government bodies. Derogations regarding the assumption of the modernization of the normative packages in the field can produce negative effects regarding the competitiveness of Moldovan products, in relation to the European partners, in the context of the liberalization of the agri-food market in the Republic of Moldova.

The results of the official controls performed by the National Agency for Food Safety (ANSA) 2016-2019.
In the Republic of Moldova compliance with food safety legislation, is verified by the national food safety authority ANSA through official controls.

In the absence of a system for disclosing inspections in the field of food safety at national level which, according to the authors J Kaskela, A Vainio, S Ollilad, J Lundéna (2019), aim to increase the effectiveness of official controls, the analysis of the results of official controls is of increased interest for the evaluation of the control system in the Republic of Moldova.

The results of official food safety controls are presented in the annual reports on the implementation of ANSA's multi-annual control plan. The analysis in question is limited to a period of 4 years.

The procedural aspects of the inspections are established in the Multiannual Control Plan 2019-2022. The frequency of official controls is determined according to the risk group in which the economic operator is classified. In the risk analysis, if the assessment of a risk criterion shows that the person subject to control produces, processes / handles products or carries out several types of activities, which fall into different degrees of risk, the highest degree of risk is assigned. risk according to GD $1280 / 2018$.

History of the results of the last compliance check with the establishment of nonconformities and their characteristics indicate a high degree of risk.

Another important factor in determining the degree of risk of the operator is the type of food product and the raw material used to obtain the food.

The application of risk analysis principles and critical control points HACCP becomes a mandatory factor in determining the frequency of controls. Food business operators who have not elaborate permanent procedures based on HACCP principles are classified in the increased risk group with a maximum score of 5 points in this position. 
The measures applied following the official controls by the competent authority in the
Republic of Moldova are: prescriptions, contravention fines, suspension of activity.

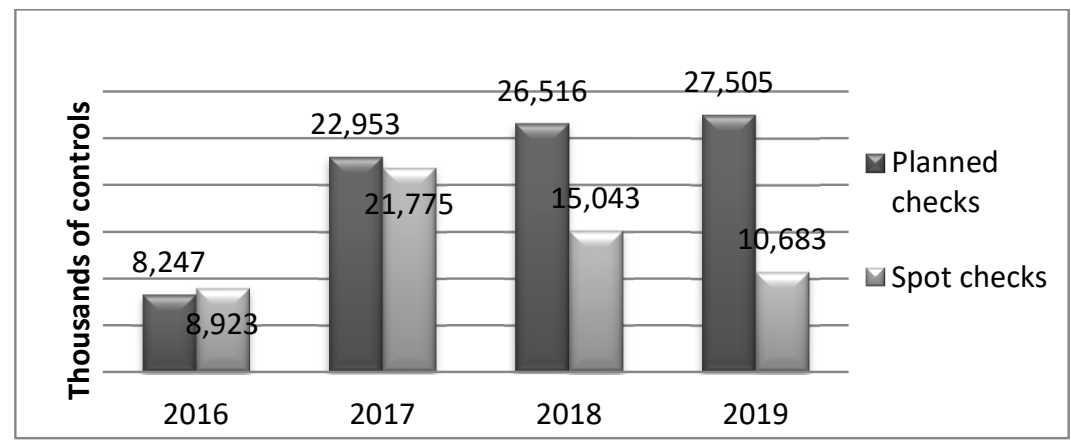

Figure 1: Governmental official controls (2016-2019)

Source: Elaborated by the author based on ANSA Reports (2016-2019) and V. Zanet, S. Stanciu (2020).

The data in Figure 1 show that the control authority has essentially reduced the number of unplanned controls, but in parallel the number of planned controls has increased. It should be noted that official unplanned controls may occur as a result of complaints from the consumer. Another basic factor in carrying out planned official controls is the possession of truthful information on the existence of a high risk. Increasing the number of planned official controls and reducing the number of unplanned controls summarizes the fact that the authority applies the history of the result of the last control to the planning of controls.

The system of official state controls in accordance with the Multiannual National Control Plan 2018-2022 (ANSA, 2018), is:

- Control system in the sanitary-veterinary field (SCSV)

- Control system for zoo- technical surveillance (SCSZ)

- Control system of processing units for food of animal origin (SCFAO)

- Control system of processing units for food of non-animal origin (SCFVO)

- Control system of wine products, ethyl alcohol, beer and alcoholic production. (SCPWA)
- Control system of trade units and public catering, and consumer protection (SCPC)

- Veterinary Medicine Products Control System (SCPMV)

- Feed and Animal Nutrition Unit Control System (SCAN)

- Control system for imports of live animals, plants and food (SCIAPF)

- Plant Health Control System and Plant Protection Products (SCPPP).

The system of official state controls in accordance with the Multiannual National Control Plan 2018-2022 (PNMAC) fully covers the activities of the competent authority regarding the planned official control and the priorities established for the implementation period of the plan. The document also describes the procedures for monitoring and reporting on the progress of the implementation of the PNMAC.

The results of the official controls are presented in the Annual Reports on the implementation of the Multiannual National Control Plan, respectively for the years 2016-2019 the authority reported 141,645 controls performed establishing 39,717 non-compliances. 
Table 1: ANSA actions within the official controls

\begin{tabular}{|c|c|c|c|}
\hline Year & $\begin{array}{c}\text { Number of } \\
\text { checks }\end{array}$ & $\begin{array}{c}\text { Number of non- } \\
\text { compliance }\end{array}$ & Non-compliance \% \\
\hline 2016 & 17,17 & 5325 & 31.01 \\
\hline 2017 & 44,728 & 12,358 & 27.63 \\
\hline 2018 & 41,559 & 14,305 & 34.42 \\
\hline 2019 & 38,188 & 7728 & 22.63 \\
\hline Total & $\mathbf{1 4 1 , 6 4 5}$ & $\mathbf{3 9 , 7 1 7}$ & $\mathbf{2 3 . 1 3}$ \\
\hline
\end{tabular}

Source: Elaborated by the author based on the yearly ANSA Reports (2016-2019 and V. Zanet, S. Stanciu (2020).

The national authority for food safety between 2016-2019 carried out 141,645 official controls setting a non-compliance rate of $23.13 \%$. The highest non-compliance rate was set by the authority in 2018 with a maximum of $34.42 \%$, the lowest rate of nonconformities was registered in 2019 with values of $22.63 \%$.

Table 2: Indices of complaints for non-conformities compared to all control systems 2016-2019

\begin{tabular}{|c|c|c|c|c|c|c|}
\hline Yars & $\begin{array}{l}\text { Type of } \\
\text { control } \\
\text { system }\end{array}$ & $\begin{array}{l}\text { Number } \\
\text { of } \\
\text { checks }\end{array}$ & $\begin{array}{l}\text { Number of } \\
\text { non- } \\
\text { compliance }\end{array}$ & $\begin{array}{l}\text { Official } \\
\text { control } \\
\text { rate } \%\end{array}$ & $\begin{array}{l}\text { Rate of non- } \\
\text { compliance } \\
\%\end{array}$ & $\begin{array}{l}\text { Index of } \\
\text { non- } \\
\text { compliance }\end{array}$ \\
\hline \multirow[t]{5}{*}{2016} & SCSV & 4377 & 1451 & 25.49 & 27.24 & 1.75 \\
\hline & SCSZ & 3601 & 955 & 29.97 & 17.93 & -12.04 \\
\hline & SCFAO & 1969 & 1164 & 11.46 & 21.85 & 10.39 \\
\hline & SCFVO & 594 & 14 & 3.45 & 0.26 & -3.19 \\
\hline & SCPC & 4670 & 1158 & 27.19 & 21.74 & -5.45 \\
\hline \multirow[t]{5}{*}{2017} & SCSV & 9171 & 2400 & 20.50 & 19.42 & -1.08 \\
\hline & SCSZ & 10,713 & 1112 & 23.95 & 8.99 & -14.96 \\
\hline & SCFAO & 1983 & 957 & 4.43 & 7.74 & 3.31 \\
\hline & SCFVO & 1326 & 359 & 2.96 & 2.9 & -0.06 \\
\hline & SCPC & 14,972 & 5210 & 33.47 & 42.15 & 8.68 \\
\hline \multirow[t]{5}{*}{2018} & SCSV & 6486 & 3393 & 15.6 & 23.71 & 8.11 \\
\hline & SCSZ & 10,977 & 1201 & 26.41 & 8.39 & -18.02 \\
\hline & SCFAO & 1924 & 814 & 4.62 & 5.69 & 1.07 \\
\hline & SCFVO & 1697 & 603 & 4.08 & 4.21 & 0.13 \\
\hline & SCPC & 15,939 & 6907 & 38.35 & 48.28 & 9.93 \\
\hline \multirow[t]{5}{*}{2019} & SCSV & 3704 & - & 9.69 & - & - \\
\hline & SCSZ & 11,287 & 1061 & 29.55 & 13.72 & -15.83 \\
\hline & SCFAO & 2003 & 1483 & 5.24 & 19.18 & 13.94 \\
\hline & SCFVO & 1583 & 665 & 4.14 & 8.6 & 4.46 \\
\hline & SCPC & 16,264 & 3728 & 42.58 & 48.0 & 5.42 \\
\hline \multicolumn{2}{|c|}{$\begin{array}{c}\text { Total/Average } \\
\text { rate }\end{array}$} & 110,283 & 34,635 & 18.15 & 17.5 & -0.17 \\
\hline
\end{tabular}

Source: Elaborated by the author based on the yearly ANSA Reports (2016-2019).

Vitalii ZANET and Silvius STANCIU, Journal of Eastern Europe Research in Business and Economics, DOI: 10.5171/2021.138785 
The data interpreted in Table 2 demonstrate that the planned and unforeseen official controls on the livestock sector (SCSZ), take negative values of the Non-compliance Index compared to all control systems with increasing trends for each year. For the year $2018 I_{n c}$ at this system of official controls was established 18.02. This proves that the supervisory authority could review the number of official controls in this area. The control system of food processing units of animal origin (SCFAO) is ranked with the highest degree of risk, having positive values for 2016 of 10.39 and for 2019 of 13.94. For this type of official control system we can claim that the rate of non-conformities is higher than the rate of controls performed. Increased risk for food safety is also the domain of trade units and public catering (SCPC), registering values for $2017 I_{n c}=8.68$ and for $2018 I_{n c}=9.93$. It should be noted that the supervisory authority detected the increased risk in these types of units, planning and carrying out official controls more frequently in these types of units.

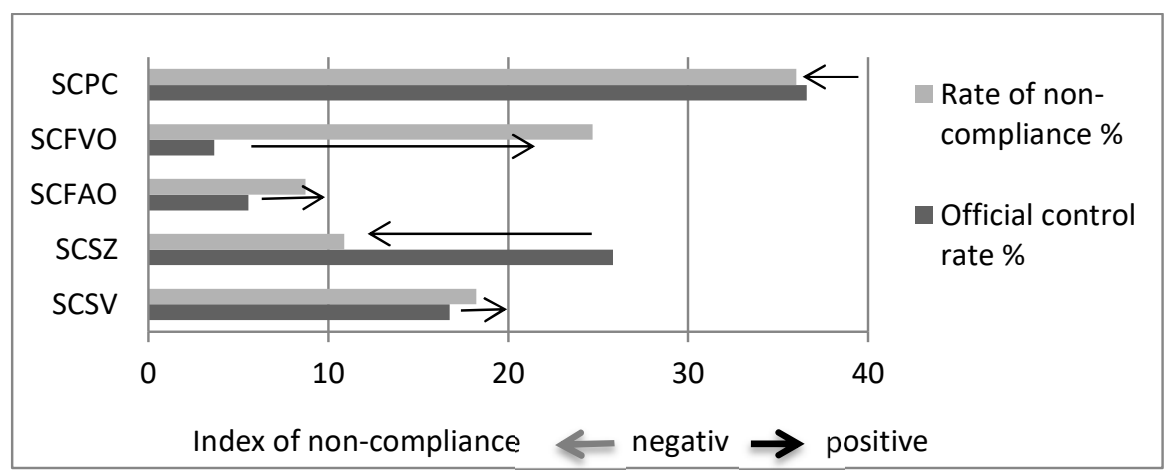

Figure2: Complaint Index for non-compliances 2016-2019.

Source: Elaborated by the author based on the yearly ANSA Reports (2016-2019).

During 2016-2019, the highest control rate within the official control system was registered in the field of trade units and public catering (SCPC) with a rate of $36.6 \%$, and the rate of non-conformities being $36.01 \%$. The index of complaints for nonconformities being $I_{n c}=-0.59$. This indicator would mean that the ratio between noncompliances and controls is equivalent.

The system of official controls of food processing units of non-animal origin (SCFVO), registers $I_{n c}=21.01$ for the years 2016-2019. The rate of non-conformities for this system is $24.68 \%$.

For the zoo-technical surveillance control system (SCSZ), $I_{n c}=-14.93$, and the noncompliance rate is $10.89 \%$. This indicator demonstrates that for this type of units the controls are planned to be performed at a high frequency, without taking into account the results of previous controls.

The control system of food processing units of animal origin (SCFAO), records values of $I_{n c}=-3.18$ for the period 2016-2019.

\section{Conclusions}

The system of official control in the Republic of Moldova in the last decade shows positive trends regarding the revision of legislative packages. A negative aspect of the control system is the lack of massive application of HCCP principles by economic operators in the food business. This factor obliges state authorities to ensure food safety control in all aspects through the national food safety authority. The results of the official controls analyzed show that the authority on certain control

Vitalii ZANET and Silvius STANCIU, Journal of Eastern Europe Research in Business and Economics, DOI: 10.5171/2021.138785 
systems shows positive trends in the planning and performance of controls based on the results of official controls. The weakest link of the system of official controls are registered by the system of official controls in the field of animal breeding where the number of nonconformities detected cannot motivate such a high frequency of the number of controls. The system of official controls in trade units and catering establishments records the highest rate of controls performed, but at the same time the proportion between controls and non-conformities is balanced.

\section{References}

- Agenția Naţională pentru Siguranța Alimentelor ANSA, (2016), Planul național multianual de control 20182022, available at http://ansa.gov.md/uploads/files/Ordi nele\%20ANSA/Rapoarte/

Plan\%20National\%20Multianual\%

20de\%20Control.pdf, accessed 10.11.2020.

- Agenția Naţională pentru Siguranța Alimentelor ANSA, (2017), Raportul Anual 2016 privind implementarea Planului Naţional Multianual de Control 2016-2020, Chișinău, available at http://ansa.gov.md/uploads/files/Ordi nele\%20ANSA/Rapoarte/Raport\%20Co ordonat $\% 20(1)$.docx, accessed 12.04.2020

- Agenția Națională pentru Siguranța Alimentelor ANSA, (2018), Procedură generală privind pregătirea și efectuarea controlului oficial la unitățile din domeniu siguranței alimentelor, available

at

http://www.ansa.gov.md/uploads/files /SIgurantaOrigAnimala/PROCEDURI/Pr ocedura\%20General\%C4\%83\%20privi nd\%20preg\%C4\%83tirea\%20\%C8\%99 i\%20efectuarea $\% 20$ controlului $\% 20$ ofic ial\%20la\%20unit\%C4\%83\%C8\%9Bile $\% 20$ din $\% 20$ domeniul\%20siguran\%C8 \%9Ba\%20alimentelor\%20COD\%20PG13\%2002(1).pdf accessed 23.10.2020.

- Agenția Națională pentru Siguranța Alimentelor ANSA, (2018), Raportul Anual 2017 privind implementarea Planului Național Multianual de Control 2016-2020, Chișinău, available at
http://ansa.gov.md/uploads/files/Tran sparenta/RAPOARTE/Raport\%20defini tivat.pdf, accesssed 16.01.2020.

- Agenția Națională pentru Siguranța Alimentelor ANSA, (2019), Raportul Anual 2018 privind implementarea Planului Național Multianual de Control 2018-2022, Chișinău, available at http://www.ansa.gov.md/uploads/files /Transparenta/Raport\%20planul\%20m ultianual $\% 20 \mathrm{de} \% 20$ control $\% 202018 \%$ 20(3)\%20modificat.pdf, accessed 23.10.2020.

- Agenția Națională pentru Siguranța Alimentelor ANSA, (2019), Raportul Anual 2019 privind implementarea Planului Național Multianual de Control 2018-2022, Chișinău, available at http://www.ansa.gov.md/uploads/files /Transparenta/Raport\%20planul\%20m ultianual $\% 20 \mathrm{de} \% 20$ control $\% 202018 \%$ 20(3)\%20modificat.pdf, accessed 23.10.2020.

- Ministerul Afacerilor Externe și Integrării Europene, 2019, Raportul privind realizarea Planului Naţional de Acţiuni pentru implementarea Acordului de Asociere RM-UE, acesibil https://mfa.gov.md/sites/default/files/ raportul_pnaaa_2017-2019__semestrul_i_2019.pdf - accessed 26.11.2020.

- Guvernul Republicii Moldova, (2019), Hotărâre cu privire la aprobarea Strategiei în domeniul siguranţei alimentelor pentru anii 2018-2022 (draft), available at https://gov.md/sites/default/files/doc ument/attachments/intr15_126.pdf, accessed 10.12.2020.

- J. Lueckla, K. Weyermaira, M. Mattb , K. Mannerc and K. Fuchsa, (2019), Results of official food control in Austria 20102016. available at

- https://www.researchgate.net/publicat ion/329764251_Results_of_official_food _control_in_Austria_2010-2016 accessed 19.09.2020.

- Steven M. Buco, (1990) How good are your results? An approach to qualitative and quantitative statistical analysis for food monitoring and process control systems, available https://www.sciencedirect.com/science

Vitalii ZANET and Silvius STANCIU, Journal of Eastern Europe Research in Business and Economics, DOI: 10.5171/2021.138785 
/article/abs/pii/0956713590901202 accessed 04.01.2021.

- Pavla Svrčinová, Vladimír Janout,(2018), Comparison of official food safety control systems in member states of the European Union, available athttp://cejph.szu.cz/pdfs/cjp/2018/0 4/13.pdf

- J. Kaskela, A. Vainio, S. Ollilad, J Lundéna (2019), Food business operators' opinions on disclosed food safety inspections and occurrence of disagreements with inspector grading available https://www.sciencedirect.com/science /article/pii/S0956713519302609 accessed 18.01.2021.

- V.Zanet, S. Stanciu (2020), Ensuring Safe Food in Moldova. Controls, Results and Conclusions for 2016-2018, 35th IBIMA Conference, Seville, Spain, April 1-2, 2020, ISBN: 978-0-9998551-4-0. 